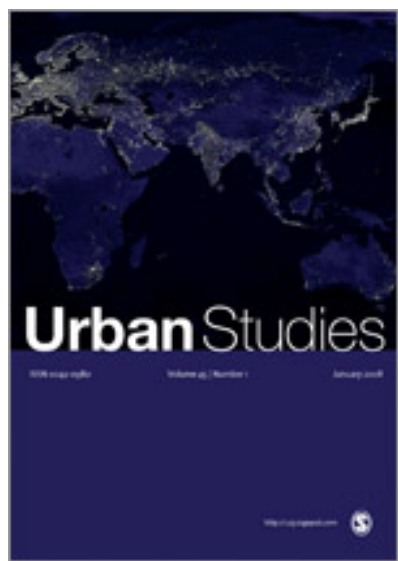

\title{
IN SEARCH OF THE SKILLED CITY: SKILLS AND THE OCCUPATIONAL EVOLUTION OF BRITISH CITIES
}

\begin{tabular}{|c|c|}
\hline Journal: & Urban Studies \\
\hline Manuscript ID & CUS-504-18-05.R2 \\
\hline Manuscript Type: & Debates Paper \\
\hline $\begin{array}{l}<b>\text { Discipline: Please select a } \\
\text { keyword from the following } \\
\text { list that best describes the } \\
\text { discipline used in your paper.: }\end{array}$ & Geography \\
\hline $\begin{array}{l}\text { World Region: Please select } \\
\text { the region(s) that best reflect } \\
\text { the focus of your paper. } \\
\text { Names of individual countries, } \\
\text { cities \& economic groupings } \\
\text { should appear in the title } \\
\text { where appropriate.: }\end{array}$ & Western Europe \\
\hline $\begin{array}{r}\text { Major Topic: Please identify } \\
\text { up to } 5 \text { topics that best } \\
\text { identify the subject of your } \\
\text { article.: }\end{array}$ & Economic Processes, Agglomeration/Urbanisation, Employment/Labour \\
\hline $\begin{array}{r}\text { You may add up to } 2 \text { further } \\
\text { relevant keywords of your } \\
\text { choosing below: }\end{array}$ & Skills \\
\hline
\end{tabular}

\section{SCHOLARONE" Manuscripts}




\title{
IN SEARCH OF THE SKILLED CITY: SKILLS AND THE OCCUPATIONAL EVOLUTION OF BRITISH CITIES
}

\begin{abstract}
Recent research has argued that human capital has become the key driver of city growth and that there is a widening divergence between high and low-skill cities. This skilled city view includes several stylised propositions. The first is that more skills and human capital generate stronger economic growth; the second is that already skilled cities are becoming ever more skilled; and, the third is that larger cities tend to have stronger concentrations of, and faster growth in, high-skilled, cognitive occupations. Using a detailed dataset for occupational change in 85 urban Travel to Work Areas in Britain between 1981 and 2015, this paper evaluates whether these propositions apply to British urban evolution, and how they relate to the 'hollowing-out' of medium-skilled jobs. The results confirm the close interactive relationship between growth and high-skilled occupations. However, some of the skilled city propositions, such as 'smart cities becoming smarter', and a positive relationship between agglomeration and high skilled employment growth, do not apply in Britain where other factors have been more important. The pattern of high-skill growth has shown a strong regional dimension, and the 'emergence' of newer smaller cities, particularly in southern England has been more evident than the 'resurgence' of large core and industrial cities.
\end{abstract}

Keywords: Economic Processes, Agglomeration/Urbanisation, Employment/Labour, Skills

\section{Introduction}

The accumulation of skills and human capital are central to the process of urban economic growth (Chinitz 1961). Moreover, the significance of skilled occupations is said to have increased dramatically in recent decades and become crucial to post-industrial city growth and the main priority for urban economic policy (Cheshire et al. 2014, HM Government, 2011). According to Parkinson (2016, p. 632), for example, “A skilled workforce is a critical feature of competitive cities. Modern economies increasingly depend upon knowledge-intensive 
sectors, even within manufacturing. Policymakers and businesses typically rate this as the most significant single factor".

Despite the broad consensus on the importance of skills, much less agreement exists on exactly how skills and skilled occupations are changing across cities. Instead, there are several influential narratives about how skills are shaping the dynamism of city economies. One argues that there is an increasing divergence between high and low-skill cities which is producing a 'winner takes all' geography in which skilled people are drawn to successful cities (Moretti, 2013). Another envisages the consolidation of skills-equilibria in different urban economies with labour supply and demand for skilled occupations at different skill levels becoming matched at low, medium or high positions (Green, et al., 2016). A further interpretation, popular in the UK, is that economic growth has been held back by education failures, shortages in skills supply, insufficient connection with employer needs, and limited devolution over skills policy (Brown et al. 2018, CBI, 2016).

Despite these debates, there has been a relative lack of research on the geography of skilled occupations and their changes through time, especially outside of the US ${ }^{1}$. Furthermore, skills, and their use and application in particular jobs, are notoriously difficult to measure directly (Bacolod et al., 2009). This paper aims to begin to remedy this lack of research. It starts by examining research on the rise of the 'skilled city' and identifies its three main propositions about the relations between city characteristics and skilled jobs. The first is that the proportion of the workforce in high-skilled occupations has driven stronger employment growth across cities. The second is that initially high skilled cities have seen faster growth in high-skilled occupations, thereby widening the gap with less skilled cities. The third is that larger and denser cities have generated higher growth rates in higher-skilled occupations. Using a detailed and comprehensive dataset for occupational change in 85 cities between 1981 and 2015, the paper assesses whether these propositions help to explain the economic performance of cities in Britain. Addressing a further neglected area in the skilled city work, it then briefly examines the pattern of occupational polarisation seen in British cities over this period and identifies

\footnotetext{
${ }^{1}$ Indeed, much of the most influential literature on skills, education and city growth is based on analyses for the United States, especially the writings of Glaeser and co-authors (see, for example, Glaeser and Saiz, 2003; Glaeser and Berry, 2006) and Moretti, (2013). Peck (2016) argues that Glaeser's significant policy influence represents the construction of a neoliberal urban orthodoxy.
} 


\section{The Rise of the 'Skilled City'}

It has long been recognised that human capital is a key constituent of endogenous urban development and long-run city growth (Martin and Sunley, 1998; Simon and Nardinelli, 2002; 1996). Glaeser and Saiz (2003) find that, for more than a century, better educated cities in the US have grown faster than comparable cities with less human capital (see also Glaeser et al. 2014; Simon, 1998). Many authors have since gone further to argue that the significance of human capital has increased and become the key engine of city growth. Indeed, this research has been a principal contribution in the resurgence of urban economics and its strong influence on city policy since the 1990s (Cheshire et al., 2014). Glaeser $(2009,49)$ writes, "In the twentyfirst century, idea production appears to have become the major business of many metropolitan areas, and skilled workers seem to be the most important element in the production of ideas". Thus, "the key to urban success or failure in today's economy is simple: high-skill cities prosper; low-skill ones stagnate or decline" (Glaeser 1996, p. 3; see also Glaeser et al., 1995; Glaeser and Gottlieb, 2009). Moretti (2013), referring to the US experience, describes a 'Great Divergence' beginning in the 1980s between 'innovation-hub' cities with high educational levels, generating abundant knowledge spill-overs, and cities with poorly educated workforces and outdated industries.

The key argument here is that that the geographical concentration of skilled and educated people in cities raises productivity growth, underpinned by the stronger external economies of agglomeration in skilled cities (Glaeser and Resseger, 2010). Furthermore, globalisation has increased the economic returns from knowledge creation and dissemination, and raised the rewards for face-to-face knowledge sharing (Glaeser and Gottlieb, 2009; Glaeser, 2012). In global North economies, cities have flourished as amenity and consumption nodes rather than production centres, and as magnets and generators of creative talent (ibid.). 
Several main and stylised propositions can be distilled from this literature for closer investigation in Britain's cities. While there is varying support for, and interpretations of the causes of, these propositions, they have become recurrent and core themes echoed in many policy reports. The first is that more skills and human capital generate stronger economic growth through positive externalities that raise productivity and innovation. These externalities and spill-overs are evidenced by the wage premium paid to skilled workers in cities (Glaeser and Maré, 2001; Gabe, 2009). In a post-industrial economy, occupations that require cognitive and social intelligence skills and assets are growing, whereas those that require physical skills are declining (Scott, 2009) ${ }^{2}$. Hence, it is argued that cities with greater shares of cognitive and social types of skill are most likely to grow fastest (Bacolod et al., 2009), and to better absorb knowledge and prove more adaptable. Differences in the kinds of skilled labour concentrated in cities explain their divergent economic performance (Markusen and Schrock 2006), highlighted and popularised by claims about the 'creative class' in urban economic growth (Florida et al., 2012).

The second proposition is that skilled cities are becoming more skilled. As Glaeser and Berry (2006) put it, 'smart places are getting smarter'. More initially highly skilled and educated cities are attracting more skilled labour (Berry and Glaeser, 2005). In Moretti's (2013, p. 5) terms, "The success of a city fosters more success, as communities that can attract skilled workers and good jobs tend to attract even more. Communities that fail to attract skilled workers lose further ground". Although high-skill cities have higher factor costs, skilled workers are more productive, earn higher wages and move to these cities to get on career 'escalators and elevators' and benefit from externalities and networks that boost their experiences, earnings and careers (Gordon et al., 2015). The causes of this divergence have been debated vigorously. A people-focused approach has argued that it is driven by the location decisions of skilled individuals. This claims that skilled people choose to live close to other skilled people to again access to valuable knowledge 'windfalls' and to enjoy amenity values and higher quality consumption facilities in larger urban centres (Glaeser et al., 2001). Florida's creative class is a version of this approach, albeit with a somewhat different and wider understanding of amenities and pull-factors that are assumed to operate. An alternative production-based approach sees the uneven growth of industries, firm and innovation systems

\footnotetext{
${ }^{2}$ Although in the UK it should be noted that there is evidence that the growth in skills demand and particularly demand for numeracy and literacy skills has faltered since 2012 (Henseke et al, 2018 )
} 
large metropolitan areas in the USA are marked by especially dense concentrations of cognitive human capital, or, in other terms, mental, behavioural and cultural assets embodied in the labour force. Small metropolitan areas, in contrast, have a much greater proclivity to harbour human capital assets that entail more physical aptitudes such as strength, stamina, manual dexterity and mechanical skills.

As Storper and Manville (2006) cautioned, this proposition about size can obscure different types of agglomeration because it includes the 'emergence' of sprawling newer cities as well as the 'resurgence' of older large and industrial cities.

The growth of high skilled occupations, of course, tells only part of the story about recent occupational change. While the 'skilled city' work has focused on the top of the occupational hierarchy, the growth at the bottom and a decline in middling wage and medium skill jobs has been relatively neglected. The resulting occupational polarisation has been found in many 
mature industrialised and especially urban economies (Goos et al. 2014; Oesch and Rodriguez Menes, 2011; Michaels and Van Reenen, 2010). This 'hollowing-out' is explained primarily in terms of the impacts of computer and information technology raising demand for educated labour and eliminating routine and semi-skilled work (Autor et al., 2003; Autor, 2015). It is has also been increased by the global outsourcing of routine manufacturing employment (Hijzen et al., 2005; Gagliardi et al., 2015). The geography of this 'hollowing-out' has received relatively less attention, however, and its impacts across cities remain under-studied. Moretti (2013) argues that traditional manufacturing cities have suffered most from 'hollowing-out' and that this underlies their divergence from 'innovation hubs'. The implication, then, is that there is a negative relationship between high skilled growth and the 'hollowing-out' of middleskill occupations across cities.

Most of the empirical evidence in the 'skilled city' literature pertains to US cities (Dijkstra et al, 2013). There has been much less work on other countries, where the lack of detailed data has constrained analysis. It is unclear whether, how and when differences and path dependencies in other national and urban contexts continue to matter (Christopherson, 2002). To begin remedying this gap, this paper aims to explore these main 'skilled city' propositions in the British context. Human capital in Britain has certainly been subject to divergent spatial trajectories (Duranton and Monastiriotis, 2000; Champion et al., 2014; Green, A., 2016; Cheshire et al., 2017), although there is some debate on their significance (McCann, 2016). The UK has moved strongly to a service economy within a relatively de-regulated, although not highly geographically mobile, labour market, and its cities have experienced divergent economic trajectories since the early 1990s, if not before (Martin et al., 2016; Martin et al., 2017). Given that human capital is endogenous to economic growth, we would expect to find strong relations between skills and city divergence. Here, we test whether and how far the skilled city propositions explain the experience of British cities. Beforehand, a note on data issues is in order.

\section{Measuring Skills and Defining Occupations}

Measuring and tracking human capital and skills present substantive methodological challenges. It is difficult directly to assess the combinations of skills that workers are using in their work in different occupations at different times, and there are only a limited number of 
often partial skill surveys. Most studies are forced use some kind of proxies of skills. The skilled city literature discussed above often uses percentage of population educated to degree level. However, this educational measure has been widely criticised as some types of skill are acquired through experience and interactions with others rather than through formal education, and a college education is not a prerequisite for all high knowledge occupations (Florida et al., 2012; Gabe, 2009; Florida and Mellander, 2018). Occupation profiles are a more direct proxy of skill levels and can show more detailed types of skill differentiation (Bacolod et al., 2009). Occupations are themselves, of course, made up of a bundle of tasks and activities that may change over time. In the UK, skill surveys indicate that skills, and especially literacy and interpersonal or influencing skills, in the same occupation have been increasing (Green, F. 2016). Nevertheless, it is still useful to classify occupations by the bundles of tasks and skills that they involve in order to distinguish occupations that involve mainly cognitive and social intelligence skills from those using mainly physical and manual skills.

Unfortunately, no official, regularly collected and detailed time series data on occupations or skills are produced for the various cities in the $\mathrm{UK}^{3}$. Thus, a major step in the analysis involved the construction of as accurate and consistent a data set as possible from the few data sources on occupations and skills that do exist. Here, the method uses the division of standard occupational groups into four skill levels used by the UK Commission for Employment and Skills (Table 1). Jobs are classified in groups according to the concept of 'skill level' and 'skill specialisation'. For the UK, the four levels are distinguished by the duration of training and/or work experience as well as the qualification level required. Table 2 shows the allocation of occupational groups to the four skill levels. Focusing on the skilled city propositions, discussed above, the Level 4 group is of specific interest because its members have well above average levels of 'data' and 'people' skills (Dickerson and Wilson, 2012). A degree level qualification is normally required for jobs at Level 4 whereas Level 3 occupations typically require technical qualifications. However, Skill Level 4 usefully excludes those graduates who are not working in high-skilled jobs and includes non-graduates who have risen to senior management corporate positions.

\section{Please Insert Table 1 and Table 2 here}

\footnotetext{
${ }^{3}$ While the Labour Force Survey collects such data, the robustness of the data at smaller spatial scales is poor.
} 
Using these defintions, in what follows, we focus on 85 cities in Britain between 1981 and 20154. The cities are defined geographically by Travel to Work Areas (TTWAs) using 2011 boundaries. The key criterion is that $75 \%$ of the total workforce both lives and resides in this area. On this basis we identified 85 cities with populations above $200,000^{5}$. This dataset construction involved three main stages: i) estimating Standard Industrial Classification Standard Occupational Classification (SIC-SOC) matrices of employment by sector and occupation for each TTWA drawing upon the Working Futures 2014-24 matrices. Working Futures is a quantitative assessment of employment trends based on a detailed and comprehensive model of the UK labour market, produced by the Warwick Institute for Employment Research. We then calculated SIC-SOC data for local authority districts and converted these to TTWAs; ii) adjusting and scaling the first estimates of TTWA SIC-SOC matrices to ensure consistency with employment by occupation data and TTWA employment by sector data for 1981-2014; and, iii) extending the 2014 SIC-SOC matrices backwards to produce consistent series for 1981-2014 which involved calculating the growth rates of TTWA occupation shares of employment over the period, and applying these to employment data by sector for each year to produce TTWA employment by occupation for 1981-2014. A final data review ensured the results were internally consistent with the input data and the data calculation processes, and credible (e.g. not unusually volatile or showing other unusual patterns).

The dataset is based on rigorous estimations and utilises the most detailed information available. However, it is not free of some inconsistences and breaks over time, for example as new job classifications appear and data collection methods alter. In many TTWAs there are data

\footnotetext{
${ }^{4}$ These are the cities that are the basis of the larger Economic and Social Research Council (ESRC) project on the economic performance of British cities over 1971-2015, of which this paper forms a part (see https://www.cityevolutions.org.uk). The 85 cities concerned accounted for 84 percent of UK employment in 2015.

${ }^{5}$ This self-containment figure is based on the total workforce and produces 228 Travel To Work Areass. However, TTWAs for different occupational groups vary in size and the degree of containment in these areas will be lower for the highest skilled workers. The Office for National Statistics (ONS, 2016) estimates that there are 153 TTWAs for the highest qualified employees and 461 for the lowest qualified. Our cities therefore represent amalgamations of smaller, lower skilled TTWAs and have significant external commuting flows for the highest skilled. On the whole, however, using TTWAs to define our cities results in urban areas that have greater meaning as functional labour markets than cities defined as, say, administrative units or as contiguous built-up spaces.
} 


\section{High Skilled Occupations and Urban Economic Growth}

The first 'skilled city' proposition is that the growth of higher skills and human capital in a city generate stronger economic growth through various externalities that raise productivity, wages and innovation. We assess this by examining the relationship between total employment growth in a city over our period and the percentage of its employment in high skill Group 4 occupations in 1981, controlling for several other city-specific determinants pertinent to city economic dynamism ${ }^{6}$. For the latter, we examine the associations and relationships by including a number of variables highlighted in recent urban growth theories, namely: the log of employment as an indicator of city size (EMP81); the density of employment as an indicator of agglomeration (AGGLOM81); the shares of employment in manufacturing (MANSH81) and in knowledge intensive business services (KIBSSH81) (as indicators of economic structure); the level of productivity (PROD81); and, the degree of specialisation (or dissimilarity from the national industrial structure) measured by the Krugman Specialization Index (KSI81) ${ }^{7}$. Size,

\footnotetext{
${ }^{6}$ In this paper we examine employment growth but in an accompanying paper we focus in detail on the determinants of city productivity growth in the UK (see Martin et al, 2018).

${ }^{7}$ This is defined as

$$
K S I_{j t}=\sum_{i=1}^{N}\left|s_{i j t}-s_{i t}^{*}\right|
$$

where $s_{i j t}$ is industry $i^{\prime}$ s share of city $j^{\prime}$ s total employment, and $s_{i t}^{*}$ is that industry s share
} 
agglomeration and specialisation in high human capital sectors are typically argued to have positive effects (see Duranton and Puga 2014), although there is much debate about whether specialisation or diversity are in better for fostering long-run city employment growth (Storper,2013; Martin et al, 2016).

The simple correlations between city employment growth and these city-specific variables are shown in Table 3. As expected, there is clearly a strong positive relationship between the share of high skills and employment growth: cities that initially had a high proportion of their employment in high skill occupations were also those that experienced the fastest rates of employment growth over the subsequent period. This finding is thus in line with the proposition that skilled cities tend to grow faster than less skilled one. However, the relationships between employment growth and the indicators of city size and density are negative which does not support the interpretation that agglomeration has driven employment growth. As expected, the relationship between employment growth and manufacturing share is negative. The first two decades of our period, 1981-2001, saw sustained deindustrialization in many cities, while the correlation with KIBs share is positive given the transition to service-based urban economies. Cities with initially high productivity levels saw faster employment growth over the period which is likely caused by their stronger firm dynamics and by more productive firms expanding their market shares. Interestingly, the specialization index is not strongly associated with employment growth. Specialization and the high skill share show a negative relationship, suggesting that to the extent that cities are specialised, it is in less skilled sectors.

\section{Please Insert Table 3 here}

In order to gauge whether the 'skilled city' findings can be replicated for our data we used an employment growth regression. In fact, empirical verification of the skilled city hypothesis has typically relied primarily on regression results, and regression has been the main method used by the influential work on urban growth. Crucially, it has been used to isolate the effects of human capital on economic growth relative to other 'control' factors that are often hypothesised as influencing economic performance (see for example, Glaeser and Saiz 2003; Glaeser and Maré, 2006). Much of this work has focused on US cities, a characteristic study being that by Simon and Nardinelli (2002) who sought to assess the impact of skilled human capital on the

of total national employment. 
employment growth across US cities over the course of the twentieth century. In line with this body of work, we try here, in effect, to test and replicate these results for our British cities. Table 4 shows the results of a least squares regression for employment growth using these variables. In this regression, we add selected other variables potentially significant to urban growth in contemporary Britain. First, after Simon and Nardinelli (2002), we have used regional dummies (SE, SW, etc.) to assess whether regional location has an effect upon employment growth over and above the other characteristics of cities. Second, we include a capital city dummy (CAPCIT) to test whether London, Edinburgh and Cardiff have benefited from a discernible devolution and political decision-making centre effect. Finally, we include a New Town dummy (NWDUM) to assess whether the New Towns in our set of cities have benefited from this status and its associated institutional capabilities, resources and growth opportunities. Table 3 shows our final regression with only significant results ( $p$-value at 0.1 or lower). The full regression is given in Appendix A.

\section{Please Insert Table 4 here}

The regression confirms that a city's employment growth has been strongly and positively affected by its relative share of high skilled workers. Indeed, this effect is stronger here than in other comparable studies (e.g. Simon and Nardinelli 2002). However, the results do not support the claim that this is due to the agglomeration of high-skilled workers in large and dense cities. In fact, the results indicate that smaller and lower density labour market areas grew employment faster than larger and higher density ones. The more productive areas in 1981 also grew most strongly in employment over the 1981-2015 period. While its significance is marginal, there is an indication that employment growth was negatively affected by economic specialization for the reasons suggested above. The regional dummies show a strong disadvantage for some northern and western regions. Cities in the North East, North West, Wales and Scotland on average had less employment growth than in the other areas, even when taking other factors such as skills and productivity differences into account. In contrast, there was a strong positive effect from New Town status. This may be because New Towns offered local conditions more conducive to employment growth than elsewhere, such as more permissive and streamlined planning, cheaper land and better infrastructure. However, we should be cautious as our set of cities include only five of the largest and most successful New Towns, with strong locational advantages. In the following section, we investigate whether these results are underlain by a divergence in skill levels across British cities. 


\section{Occupational Divergence across Cities?}

As we have seen, the skilled cities research suggests that cities with more skilled employment profiles are growing fastest in terms of the accumulation of skilled labour. Figure 1 shows the relationship between share of total employment in high skill (Level 4) occupations in 1981 and the growth of this occupation group between 1981 and 2015. If 'smart places are becoming smarter', then we would expect to see a strong positive relationship. The results clearly do not support the proposition and raise doubts about how far it applies in the case of Britain. In fact, it appears that there is only a very weak positive relationship, which is not statistically significant. There are quite a number of cities that had relatively low levels of highly skilled occupations in 1981 but which have seen strong growth in these skilled jobs, and conversely, there are others which were already skilled but have seen only slow growth. However, there do appear to be differences between cities in the north and south of the country. ${ }^{8}$ There is a group of northern cities that have both a weak starting point and low rates of high skill growth. In contrast, there is a group of predominantly Southern cities with well above average starting levels but with a very large range of growth. Some of these cities have benefited from the strongest rates of growth while others have experienced only average high-skill growth. Figure 1 shows the generally stronger outcomes in the south. ${ }^{9}$

\section{Please Insert Figure 1 here}

There does not appear to be a simple divergent pattern between high and low skill cities. While the national share of employment in our high skill occupations has increased from 24 to 26.8 percent, over 1981-2015, striking differences in the nature of urban labour markets have been highly persistent. Indeed, the most cities have high-skill rates that are around twice (near 140\% of the national average) those of the least skilled cities (around $70 \%$ of the national average)

\footnotetext{
${ }^{8}$ Here we follow a conventional definition, and define Northern cities as those located in Scotland, Wales, the North East, North West, Yorkshire- Humberside and West Midlands.

9 There are two clear outliers: Leamington Spa, which is highly skilled, and Mansfield which is very lowskilled.
} 
(Figure 2). What is clear is that, unlike in the US, there is little evidence of any new 'great divergence'. Indeed, if anything, there is a very slight trend towards convergence.

\title{
Please Insert Figure 2 here
}

\begin{abstract}
Addressing its relative neglect, at the bottom end of the skills distribution Figure 3 shows the relationship between the percentage of employment in low skill group (1) and change over the period for both northern and southern cities. For both groups of cities, there is evidence of a negative relationship: TTWAs with low levels of low skill employment have tended to see a faster increase in these types of jobs. There has been a greater range of growth in southern cities, but in general there has been a convergence as low-skilled employment has grown. Once again, this is at odds with the idea of a US-style 'great divergence' in skills.
\end{abstract}

\section{Please Insert Figure 3 here}

The third stylised proposition is the claim that larger cities have larger concentrations of highskill occupations, and have seen faster growth in these occupations. We assess this by looking at relationships between city population size and change in the high-skilled and cognitive skills groups. Figure 4 shows that there is no evidence that the largest cities have seen faster growth in high-skilled occupations. Instead, there is only a very weak negative relationship which indicates that the larger cities in Britain (with the exception of London) have tended to see slower growth in high skilled occupations. At the same time, agglomeration, proxied here by employment density (employment per km squared), has not been a key driver of high-skill growth (Figure 5). The range of performance for low-density cities has been much wider than the range of performance of higher density cities. Thus, the fastest growth in employment in high skilled occupations has evidently been in some relatively low density cities, which raises profound questions about the stylised relationships between agglomeration and the growth of high skilled industries and occupations claimed in several studies.

\section{Please Insert Figure 4 here}

\section{Please Insert Figure 5 here}


Partly as a result of these trends, at the end of our period there is virtually no relationship across cities between their population size and the level of employment in high skill group level 4. Any positive relationship disappears when London is excluded. We can conclude that size of city alone tells us little about the prevalence of skilled occupations across British cities. However, when we examine distance to London there does appear to be a modest negative relationship. Growth has been faster in high skill occupations in cities closer to London (Figure 6), and, in fact, a very similar relationship exists for the lowest skilled occupations. It may well be of course that faster high skill growth raises low skill growth through demand linkages. The vibrancy of the regional labour market appears to be a much more significant factor than size or density of a city. The weight of evidence suggests that the north-south divide appears to be much more significant than either size of city, or its initial starting point, in terms of effects on changes to skill levels.

\section{Please Insert Figure 6 here}

\section{Occupational Polarisation in British Cities}

Job polarisation has been evident in the UK's labour market over recent decades as the effects of technological change and offshoring have increased high-skilled employment, but hollowedout medium skill level jobs and occupations. To date, however, there have been few investigations of the geography of this process. To start to examine this geography, a conventional assessment of job quality has been undertaken and the nine major occupational groups ranked by the median hourly wages level in 1998 (Table 5). These wages are based on SOC 1990 groups, whereas our analysis is based on SOC 2010, so there may be some small discrepancies between the make-up of the major occupational groups. To address these, we have therefore compared the rankings of the occupational groups in 1998 with those in 2016. The only change is the administrative and secretarial group has jumped over process, plant and machine operatives in terms of hourly wage. With this exception, the rankings shown are stable 
and the relative position in 1998 provides a useful indication of the rewards from work in each group. In the figures in this section the numbers of occupational groups refer to their wage rankings and not to the conventional numbers of the SOC Major Groups.

\section{Please Insert Table 5 here}

Figure 7 shows the share of employment in these occupational groups in northern and southern cities in 1981. At that time northern cities had a higher share in occupational groups associated with manufacturing such as skilled trades (4), and plant and process operatives (5), while southern cities already had higher shares in the skilled and professional occupations (1 to 3 ). Figure 8 displays the changes in shares over the period and suggests there has been a trend towards a convergence in occupational structure. Such shifts have been stronger in northern cities where the shares at the top and bottom of the scale have been higher, and the middling occupation groups in these cities have fallen to a much greater degree. On these measures, polarisation has been stronger and more disruptive in northern cities. We can investigate some of the causes further by looking at the absolute rates of change in these same occupation groups.

\section{Please Insert Figure 7 here}

\section{Please Insert Figure 8 here}

Figure 9 shows the annual average change in each of the major occupational groups (ranked according to wages). It shows that the fastest employment growth has been in the Group ranked 7 (caring, leisure and other service occupations) followed by highest ranked professional occupation group. Nationally, the middle-wage occupation groups ranked 4 (skill trades) and 5 (process, plant and machine operatives) have either stagnated or declined. Overall, the findings confirm that the UK has seen a huge growth in relatively low skilled and low-wage jobs which is indicative of a shift in growth away from higher productivity toward lower productivity service industries. Again, there are significant differences between northern and southern cities. It is notable that in both sets of cities employment growth has been strong in Groups 6 (administrative and secretarial), 7 (care and leisure), and 8 (sales and customer service). Southern cities have seen marginally faster growth in elementary low-skilled 
occupations. For the professional group, growth in northern cities has been slightly lower than in southern cities, and much lower in the manager and senior officials group, which, given the growth in public sector employment over the period, is an indication of a much less dynamic private sector in these cities. The most significant contrast is in the middle of the distribution; while employment growth in middle wage occupations in southern cities has been low, in northern cities it has been negative. Job polarisation, then, appears more pronounced in northern cities.

\section{Please Insert Figure 9 here}

Smaller, traditionally industrial northern cities, such as Stoke, Sunderland and Middlesbrough have tended to see only very weak growth in higher-paying occupations and have benefited to only a small degree from the rise of professional and managerial employment. In contrast, the fastest growing smaller cities such as Milton Keynes, Basingstoke and Oxford have not only benefitted strongly from the growth of professional and managerial classes but they have also retained some growth in a range of medium-wage occupations. Figure 10 shows the relationships between high and medium wage occupations. In northern cities there is little evidence of any relationship between Groups 1 and 5, while in southern cities there is a small positive relationship. This may be due to the demand externalities in local labour markets generated by high-skilled jobs (Moretti, 2013).

How, then, could we explain the strength of this geographical polarisation? It is unlikely that regional differences in the growth in graduate labour are primarily responsible given southern regions have higher concentrations (ONS, 2013). Instead, it appears that the impacts of information technology, automation, trade and outsourcing have had uneven spatial effects and that their negative effects on routine work have been felt more in cities that have experienced more severe deindustrialisation. While professional employment and the demand for high skills have grown in most cities, the reduction in middle-skill occupations appears more spatially uneven. In conclusion, we turn to some of the implications of these under-researched skill geographies.

\section{Please Insert Figure 10 here}




\section{Conclusions}

In sum, the 'skilled city' view is only partially applicable to the economic evolution of cities in Britain since the early 1980s. There is a clear and strong relationship between the growth of more highly skilled occupations and total employment across these cities, reinforcing accounts of the recursive relationship between skilled labour accumulations and city economic growth (Storper and Scott, 2009). The presence of firms with more skilled employment is associated with faster employment growth, confirming the 'skilled city' arguments concerning the quality of firms and the mutually reinforcing combination of productivity, externalities, spill-over and innovation effects. But what our results also reveal is that more skilled cities do not always continue automatically to increase their advantage over other cities in a cumulative way. Instead, it appears that the growth of skilled occupations waxes and wanes through time, shaped by firm and industry dynamics in particular cities. While the 'skilled city' narrative contains some recognition of these processes, many of its main and stylised propositions are too simplistic and are not fully supported by this analysis in the British context. In terms of occupational change, there is no evidence of a new 'great divergence' in skills between cities in Britain. Instead, our results show a substantial and persistent gap between the most and least skilled cities, a gap that has a clear north-south dimension. Further, there is little evidence that agglomeration has been a key driver of the growth in skilled occupations. While London has seen strong high-skilled growth for part of our period, in general the smaller and lower density labour market areas, most of which are in the south of England, have grown skilled employment faster than larger and higher density ones. This analysis therefore questions and at least qualifies the claim that agglomeration is the only guaranteed way of building skilled employment and developing new and dynamic knowledge-based urban economies. Regional economic differences between northern and southern regions have been more important than the size or density of cities.

Such regional variations are important to considerations of the relatively neglected issue of job polarisation. Given our data, we have not been able to measure skill polarisation directly. Our analysis examined relative occupational polarisation and the comparative performance of cities. It revealed that occupational polarisation has been more marked in northern cites. While these cities have had faster growth in their share of employment in high skill occupations, their 
relative, and in many cases absolute, decline in medium-wage jobs has been stronger. This finding is consistent with studies of the impact of global trade, technological change and restructuring on these former manufacturing-based economies (Beatty and Fothergill, 2016). This uneven geography of occupational change has contributed to a decline in economic and political cohesion in Britain and is likely to further exacerbate regional and urban unevenness (O’Connor, 2017).

Given the significance of the skilled city narrative for urban economic policy in Britain and beyond, these initial results have important implications and open-up avenues for further work. First, given that the European urban system is known to differ from that in the US (Dijkstra, et al, 2013), it would be interesting to examine whether the rapid growth of skilled occupations in some smaller, lower density cities, and stronger occupational polarisation in former manufacturing cities, have been seen across other states, or whether they are peculiar to the UK. Second, a better understanding is needed of the conditions that favour growth in skilled employment. In particular, why are smaller and medium-sized cities showing such a wide range of results in terms of their occupational change? The 'skilled city' view risks over-emphasising city size, agglomeration and KIBs in misleading ways and relying too heavily on education as a measure of skill. Our findings suggest policy needs to acknowledge the potential and limitations of 'big city resurgence' while paying more attention to what has facilitated the rapid growth of high-skill sectors and firms in small and medium-sized cities and what else in addition to specialisation in KIBS supports urban employment growth. While our results support the common policy focus on upskilling and increasing skill levels, the relative decline in some middle-skilled occupations in northern cities raises profound challenges for this approach. As demand for some of these skills appears to have fallen substantially, the rationale for responses seeking to raise the supply of people with medium-level qualifications and skills is being undermined. Indeed, policies seeking to speed-up the diffusion of new technologies in attempts to raise productivity in such cities may well intensify these patterns. City skills policy faces the challenge of better connecting with other local economic development strategies, devising complementary and co-ordinated interventions to raise the supply and demand for skills and supporting appropriate living wage floors (Sissons and Jones, 2016). Our analysis reveals that in many northern cities, the professional group is the only major high-skilled occupational category that has shown strong growth, typically related with public sector growth. Opportunities for city policy to build upon rising demand for skilled labour in other occupational categories are fewer and any skill shortages may be limited to tightly defined, 
specific groups within occupations. Further research on those cities where medium level skills have continued to increase would be valuable here. Future work should provide more disaggregated analyses of change in specific occupations and cities to strengthen the evidence for policy. The place dimension of skills change needs to be taken more seriously, as it may well be missed by approaches that rely on generalized propositions about the 'skilled city'.

Acknowledgments: The research for this paper is part of a larger and more detailed project, funded by the ESRC's Urban Transformations Programme (ES/N006135/1 - Structural Transformation, Adaptability and City Economic Evolutions). The authors gratefully acknowledge this support. Thanks also to the other research team members David Bailey, Emil Evenhuis and Peter Tyler. 


\section{References}

Autor, D. (2015) Why are there still so many jobs? The history and future of workplace automation, The Journal of Economic Perspectives 29, 3, 3-30.

Autor, D., Levy, F. and Murnane, R. (2003) The skill content of recent technological change: An empirical exploration, Quarterly Journal of Economics 118, 4, 1270-1333.

Bacolod, M., Blum, B. and Strange, W. (2009) Skills in the city, Journal of Urban Economics 65, 136153.

Barbour, E and Markusen, A. (2007) Regional occupational and industrial structure: Does one imply the other? International Regional Science Review 30, 1, pp. 72-90.

Beatty, C. and Fothergill, S. (2016) Jobs, Welfare and Austerity: How the Destruction of Industrial Britain Casts a Shadow over Present-Day Public Finances, Centre for Regional Economic and Social Research, Sheffield Hallam University.

Berry, C. and Glaeser, E. (2005) The divergence of human capital levels across cities, NBER Working Paper 11617.

Briscoe G. and Wilson, R. (2003) Modelling UK occupational employment, International Journal of Manpower 24, 5, pp. 568-589.

Brown, J., McGuiness, F., Sandford, M. and Ward, M. (2018) Skills Devolution in England, CDP 2018/0017, House of Commons Library: London.

CBI (2016) Unlocking Regional Growth: Understanding the Drivers of Productivity across the UK's Nations and Regions, London: CBI.

Champion T., Coombes, M. and Gordon, I. (2014) How far do England's second order cities emulate London as human-capital 'escalators'?, Population, Space and Place, 20, pp. 421-433. 
Cheshire, P., Nathan, M. and Overman, H. (2014) Urban Economics and Urban Policy: Challenging Conventional Policy Wisdom, Cheltenham; Edward Elgar

Chinitz, B. (1961) Contrasts in agglomeration: New York and Pittsburgh, American Economic Review $51,2,279-289$.

Christopherson, S. (2002) Why do national labor market practices continue to diverge in the global economy? The missing link of investment rules, Economic Geography 78, 1, 1-20.

Dickerson, A. Wilson, R., Kik, G. and Dhillon, D. (2012) Developing Occupational Skills profiles for the UK: A Feasibility Study UK Commission for Employment and Skills, Evidence Report 44, www.ukces.org.uk

Dijkstra, L., Garcilazo, E. and McCann, P. (2013) The economic performance of European cities and city regions: myths and realities, European Planning Studies 21, 3, 334-354.

Duranton, G. and Monastiriotis, V. (2000) Mind the gaps: The evolution of regional inequalities in the UK 1982-1997, CEP London

Duranton, G. and Puga, D. (2014) The growth of cities, Chapter 5 in P. Aghion and S. Durlauf (Eds.)Handbook of Economic Growth Vol. 2, 781-853. London: Elsevier.

Florida R., and Mellander C. (2018) Talent, Skills, and Urban Economies, Chapter in G.Clark, M. Feldman, M. Gertler and D. Wojcik (Eds.) The New Oxford Handbook of Economic Geography, Oxford: OUP.

Florida R., Mellander C., Stolarick and Ross A, (2012) Cities, skills and wages, Journal of Economic Geography 12, 355-377.

Gabe, T. (2009) Knowledge and earnings, Journal of Regional Science 49, 3, 439-457.

Gagliardi, L., Iammarino, S. and Rodriguez-Pose, A. (2015) Offshoring and the geography of jobs in Great Britain, CEPR Discussion Paper 10855. 
Glaeser, E. (2009) The death and life of cities, Chapter 2 in R.P. Inman(Ed) Making Cities Work: Prospects and Policies for Urban America, Princeton: Princeton University Press, pages 2262.

Glaeser, E (1996) Why economists still like cities, City Journal, Spring, 1-7. http://www.cityjournal.org

Glaeser, E. (2012) The Triumph of the City: How Urban Spaces Make Us Human, Pan Books, London.

Glaeser E. and Berry, C. (2006) Why are smart places getting smarter? Rappaport Institute and Taubman Center Policy Briefs PB 2006-2. March

Glaeser, E. and Gottlieb, J. (2009) The wealth of cities: Agglomeration economies and spatial equilibrium in the United States, Journal of Economic Literature 47, 4, 983-1028.

Glaeser, E., Kolko, J. and Saiz, A. (2001) Consumer city, Journal of Economic Geography 1, 27-50.

Glaeser E. and Maré, D. (2006) Cities and skills, Journal of Labor Economics 19, 2, 316- 342.

Glaeser, E. and Resseger, M. (2010) The complementarity between cities and skills, Journal of Regional Science 50, 1, pp. 221-244.

Glaeser, E. and Saiz, A. (2003) The rise of the skilled city, NBER Working Paper 10191.

Glaeser, E., Ponzetto, G. and Tobio, K. (2014) Cities, skills and regional change, Regional Studies 48, $1,7-43$.

Glaeser, E., Scheinkman and Shkleifer, A. (1995) Economic growth in a cross-section of cities, Journal of Monetary Economics 36, 117-143.

Goos, M. and Manning, A. (2007) Lousy and lovely jobs: the rising polarization of work in Britain, The Review of Economics and Statistics 89, 1, 118-133. 
Goos, M., Manning, A. and Salomons, A. (2014) Explaining job polarization: Routine-biased technological change and offshoring, The American Economic Review 104, 8, 2509-2526.

Gordon, I. Champion, T. and Coombes, M. (2015) Urban escalators and interregional elevators: the difference that location, mobility and sectoral specialisation make to occupational progression, Environment and Planning A 47, pp. 588-606.

Green, A., Hogarth, T., Barnes, S. Gambin, L., Owen, D. and Sofroniou, N. (2016) The UK's Skill System: Training, Employability and Gaps in Provision, Future of Skills and Lifelong Learning Evidence Review, Foresight Government Office for Science.

Green, F., Felstead, A. Gallie, D. and Henseke, G. (2016) Skills and work organisation in Britain: a quarter century of change, Journal of Labour Market Research 49, 121-132.

Henseke, G., Felstead, A., Gallie, D. and Green, F. (2018) Skill Trends at Work in Britain - First Findings from the Skills and Employment Survey 2017, London: Centre for learning nd Life Chances in Knowledge Economies, UCL Institute of Education.

Hijzen, A., Görg, H. and Hine, R. (2005) International outsourcing and the skill structure of labour demand in the United Kingdom, The Economic Journal 115, 506, pp. 860-878.

HM Government (2011) Unlocking Growth in Cities, The Cabinet Office, London.

Markusen, A. and Schrock, (2006) The distinctive city: Divergent patterns in growth, hierarchy and specialisation, Urban Studies 43, 8, 1301-1323.

Martin, R. and Sunley, P. (1998) Slow convergence? The new endogenous growth theory and regional development, Economic Geography 74, 3, 201-227.

Martin, R., Sunley, P. Tyler, P. and Gardiner, B. (2016) Divergent cities in post-industrial Britain, Cambridge Journal of Regions, Economy and Society 9, 2, 269-299. 
Martin, R. Sunley, P. Gardiner, B., Evenhuis E. and Tyler, P. (2018) The city dimension of the productivity growth puzzle: the relative role of structural change and within-sector slowdown, Journal of Economic Geography 18, 539-570.

McCann, P. (2016) The UK Regional-National Economic Problem: Geography, Globalisation and Governance, London: Routledge.

Michaels, G. and Van Reenen, J. (2010) The shrinking middle, CentrePiece Magazine 15, 2, 22-26.

Michaels, G., Rauch, F. and Redding, S. (2013) Task Specialisation in US Cities from 1880-2000, CEP Discussion Paper 1186, London School of Economics

Moretti, E. (2013) The New Geography of Jobs, Boston: Mariner Books.

O'Connor, S. (2017) Robot shock threatens the most vulnerable communities, Artificial Intelligence and Robotics, The Financial Times, 19 September 2017.

Oesch, D. and Riodriguez Menes, J. (2011) Upgrading or polarization? Occupational change in Britain, Germany, Spain and Switzerland, 1990-2008, Socio-Economic Review 9, 3, 1-29.

Oguz, S. and Knight, j. (2011) Regional economic indicators with a focus on the relationship between skills and productivity, Economic and Labour Market Review Feb 2911, 133-164

Parkinson, M. (2016) UK city regions; policies, performance and prospects, Town Planning Review $87,6,629-653$.

Peck, J. (2016) Economic rationality meets celebrity urbanology: Exploring Edward Glaeser's City, International Journal of Urban and Regional Research 40, 1, 1-30.

Puga, D. (2017) The Changing Distribution of Firms and Workers Across Cities, Centro Studi Luca d'Agliano Development Studies Working paper 418. 
Salvatori, A. (2015) The anatomy of job polarisation in the UK, IZA Discussion Paper 9193, Bonn Germany.

Scott, A. (2009) Human capital resources and requirements across the metropolitan hierarchy of the USA, Journal of Economic Geography 9, 207-226.

Simon, C. (1998) Human capital and metropolitan employment growth, Journal of Urban Economics 43, 223-243.

Simon, C. (2004) Industrial reallocation across US cities, 1977-1997, Journal of Urban Economics 56, 119-143.

Simon, C. and Nardinelli, C. (1996) The talk of the town: Human capital, information and the growth of English cities, 1861-1961, Explorations in Economic History 33, 384-413.

Simon, C. and Nardinelli, C. (2002) Human capital and the rise of American cities 1900-1990, Regional Science and Urban Economics 32, 59-96.

Sissons, P. and Jones, K. (2016) Local industrial strategy and skills policy in England: Assessing the linkages and limitations - a case study of the Sheffield City Deal, Local Economy 31, 8, 857872.

Storper, M. (2015) Keys to the City: How Economics, Institutions, Social Interaction and Politics Shape Development, Princeton University Press: Princeton.

Storper, M. and Scott, A. (2009) Rethinking human capital, creativity and urban growth, Journal of Economic Geography 9, 2, pp. 147-167. 


\section{Appendix A}

Initial regression with insignificant results

Dependent Variable: EMPLGR8115

Method: Least Squares

Date: 09/14/17 Time: 13:42

Sample: 185

Included observations: 85

\begin{tabular}{ccccc}
\hline \hline Variable & Coefficient & Std. Error & t-Statistic & Prob. \\
\hline \hline C & 3.011066 & 1.176328 & 2.559717 & 0.0128 \\
HSKILLSSH81 & 0.020137 & 0.010644 & 1.891862 & 0.0630 \\
EMPL81 & -0.148121 & 0.090383 & -1.638818 & 0.1061 \\
AGGLOM81 & -0.177150 & 0.071066 & -2.492768 & 0.0152 \\
MANSH81 & -0.001876 & 0.008777 & -0.213719 & 0.8314 \\
KIBSSH81 & -0.012991 & 0.016302 & -0.796904 & 0.4284 \\
KSI81 & -0.971807 & 0.563138 & -1.725699 & 0.0892 \\
PROD81 & 0.029229 & 0.020680 & 1.413375 & 0.1623 \\
NEDUM & -0.540688 & 0.211290 & -2.558980 & 0.0128 \\
NWDUM & -0.294684 & 0.160419 & -1.836963 & 0.0708 \\
SCDUM & -0.721202 & 0.167742 & -4.299472 & 0.0001 \\
WADUM & -0.573671 & 0.221511 & -2.589812 & 0.0118 \\
LODUM & 0.146824 & 0.463247 & 0.316946 & 0.7523 \\
EMDUM & -0.102202 & 0.165313 & -0.618236 & 0.5386 \\
EEDUM & -0.062162 & 0.128728 & -0.482895 & 0.6308 \\
WMDUM & -0.023202 & 0.164221 & -0.141284 & 0.8881 \\
YHDUM & -0.244487 & 0.156473 & -1.562487 & 0.1230 \\
SWDUM & -0.015012 & 0.159301 & -0.094237 & 0.9252 \\
CAPCIT & 0.417022 & 0.267693 & 1.557837 & 0.1241 \\
NEWTOWN & 0.543435 & 0.126430 & 4.298289 & 0.0001 \\
\hline \hline & & & & \\
\hline & & & & \\
\hline
\end{tabular}




$\begin{array}{lrll}\text { R-squared } & 0.721973 & \text { Mean dependent var } & 0.756988 \\ \text { Adjusted R-squared } & 0.640703 & \text { S.D. dependent var } & 0.508699 \\ \text { S.E. of regression } & 0.304921 & \text { Akaike info criterion } & 0.664797 \\ \text { Sum squared resid } & 6.043496 & \text { Schwarz criterion } & 1.239538 \\ \text { Log likelihood } & -8.253860 & \text { Hannan-Quinn criter. } & 0.895974 \\ \text { F-statistic } & 8.883680 & \text { Durbin-Watson stat } & 2.096874 \\ \text { Prob(F-statistic) } & 0.000000 & & \end{array}$


Table 1: A Summary of Skill Levels based on SOC10 groups

\begin{tabular}{|l|l|}
\hline $\mathbf{A}$ A Summary of Skill Levels \\
\hline $\mathbf{1}$ & $\begin{array}{l}\text { Equates with general education, short periods of work-related } \\
\text { training, includes postal workers, hotel porters, cleaners and } \\
\text { catering assistants }\end{array}$ \\
\hline $\mathbf{2}$ & $\begin{array}{l}\text { Occupations require a good general education plus a longer period } \\
\text { of work-related training or work experience. These include machine } \\
\text { operation, driving, caring occupations, retailing, and clerical and } \\
\text { secretarial occupations. }\end{array}$ \\
\hline $\mathbf{3}$ & $\begin{array}{l}\text { Requires a period of post-compulsory education, e.g. technical } \\
\text { occupations, trades occupations and small businesses. Educational } \\
\text { qualifications at sub-degree level and/or a significant period of } \\
\text { work experience are typical. }\end{array}$ \\
\hline $\mathbf{4}$ & $\begin{array}{l}\text { Includes 'professional' occupations and high level managerial } \\
\text { positions in corporate enterprises or national/local government. } \\
\text { Require a degree or equivalent period of relevant work experience. }\end{array}$ \\
\hline
\end{tabular}

Source: Dickerson et al. (2012, p.72-75) 
Table 2 Allocation of Occupational Groups to Skill Levels

\begin{tabular}{|c|c|c|c|c|}
\hline & Major Group & & Sub-major Groups & $\begin{array}{l}\text { Skill } \\
\text { Level }\end{array}$ \\
\hline \multirow[t]{2}{*}{1} & \multirow[t]{2}{*}{$\begin{array}{l}\text { Managers, directors and senior } \\
\text { officials }\end{array}$} & 11 & $\begin{array}{l}\text { Corporate managers and } \\
\text { directors }\end{array}$ & 4 \\
\hline & & 12 & $\begin{array}{l}\text { Other managers and } \\
\text { proprietors }\end{array}$ & 3 \\
\hline \multirow[t]{4}{*}{2} & \multirow[t]{4}{*}{ Professional occupations } & 21 & $\begin{array}{l}\text { Science, research, } \\
\text { engineering and technology } \\
\text { professionals }\end{array}$ & 4 \\
\hline & & 22 & Health professionals & 4 \\
\hline & & 23 & $\begin{array}{l}\text { Teaching and educational } \\
\text { professionals }\end{array}$ & 4 \\
\hline & & 24 & $\begin{array}{l}\text { Business, media and public } \\
\text { service professionals }\end{array}$ & 4 \\
\hline \multirow[t]{5}{*}{3} & \multirow[t]{5}{*}{$\begin{array}{l}\text { Associate professional and } \\
\text { technical occupations }\end{array}$} & 31 & $\begin{array}{l}\text { Science, engineering and } \\
\text { technology associate } \\
\text { professionals }\end{array}$ & 3 \\
\hline & & 32 & $\begin{array}{l}\text { Health and social care } \\
\text { associate professionals }\end{array}$ & 3 \\
\hline & & 33 & $\begin{array}{l}\text { Protective service } \\
\text { occupations }\end{array}$ & 3 \\
\hline & & 34 & $\begin{array}{l}\text { Culture, media and sports } \\
\text { occupations }\end{array}$ & 3 \\
\hline & & 35 & $\begin{array}{l}\text { Business and public service } \\
\text { associate professionals }\end{array}$ & 3 \\
\hline \multirow[t]{2}{*}{4} & \multirow{2}{*}{$\begin{array}{l}\text { Administrative and secretarial } \\
\text { occupations }\end{array}$} & 41 & Administrative occupations & 2 \\
\hline & & 42 & $\begin{array}{l}\text { Secretarial and related } \\
\text { occupations }\end{array}$ & 2 \\
\hline \multirow[t]{4}{*}{5} & \multirow[t]{4}{*}{ Skilled trades occupations } & 51 & $\begin{array}{l}\text { Skilled agricultural and } \\
\text { related trades }\end{array}$ & 3 \\
\hline & & 52 & $\begin{array}{l}\text { Skilled metal, electrical and } \\
\text { electronic trades }\end{array}$ & 3 \\
\hline & & 53 & $\begin{array}{l}\text { Skilled construction and } \\
\text { building trades }\end{array}$ & 3 \\
\hline & & 54 & $\begin{array}{l}\text { Textiles, printing and other } \\
\text { skilled trades }\end{array}$ & 3 \\
\hline \multirow[t]{2}{*}{6} & \multirow[t]{2}{*}{$\begin{array}{l}\text { Caring, leisure and other service } \\
\text { occupations }\end{array}$} & 61 & $\begin{array}{l}\text { Caring personal service } \\
\text { occupations }\end{array}$ & 2 \\
\hline & & 62 & $\begin{array}{l}\text { Leisure, travel and related } \\
\text { personal service occupations }\end{array}$ & 2 \\
\hline \multirow[t]{2}{*}{7} & \multirow{2}{*}{$\begin{array}{l}\text { Sales and customer service } \\
\text { occupations }\end{array}$} & 71 & Sales occupations & 2 \\
\hline & & 72 & Customer service occupations & 2 \\
\hline \multirow[t]{2}{*}{8} & \multirow[t]{2}{*}{$\begin{array}{l}\text { Process, plants and machine } \\
\text { operatives }\end{array}$} & 81 & $\begin{array}{l}\text { Process, plant and machine } \\
\text { operatives }\end{array}$ & 2 \\
\hline & & 82 & $\begin{array}{l}\text { Transport and mobile } \\
\text { machine operatives }\end{array}$ & 2 \\
\hline 9 & Elementary occupations & 91 & $\begin{array}{l}\text { Elementary trades and related } \\
\text { occupations }\end{array}$ & 1 \\
\hline
\end{tabular}




\begin{tabular}{|l|l|l|l|}
\hline & 92 & $\begin{array}{l}\text { Elementary administration } \\
\text { and service occupations }\end{array}$ & 1 \\
\hline
\end{tabular}

Source: Dickerson et al (20120 page 75).

Table 3: Correlation Analysis

Included observations: 85

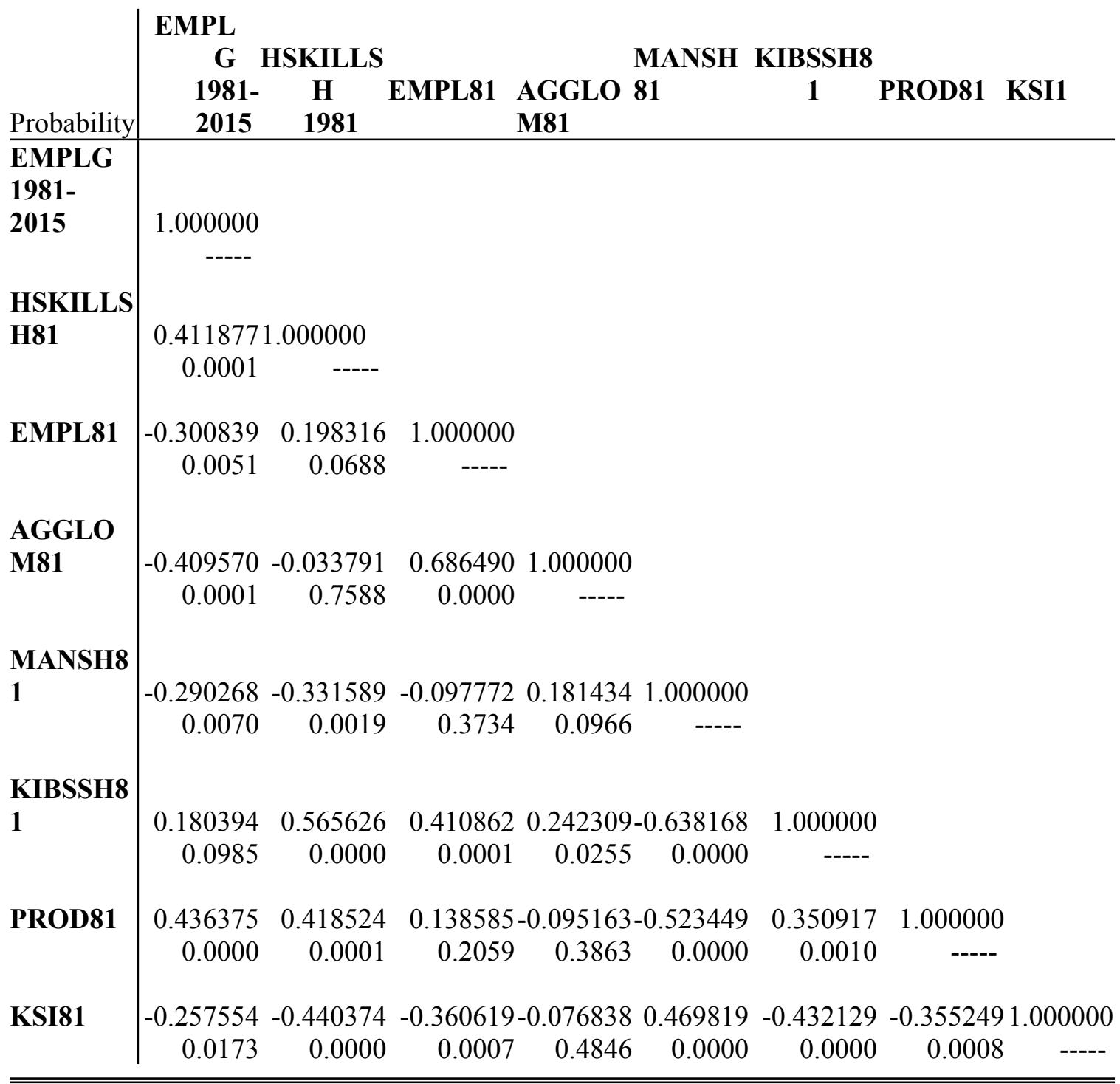




\section{Table 4: Regression Analysis}

Dependent Variable: EMPLGR1981-2015

Method: Least Squares

Included observations: 85

\begin{tabular}{lrrrr}
\hline \hline \multicolumn{1}{c}{ Variable } & Coefficient & Std. Error & t-Statistic & Prob. \\
\hline \multicolumn{1}{c}{ C } & 2.291223 & 0.905366 & 2.530715 & 0.0135 \\
HSKILLSSH81 & 0.023178 & 0.007938 & 2.919951 & 0.0047 \\
EMPL81 & -0.127834 & 0.076444 & -1.672257 & 0.0988 \\
AGGLOM81 & -0.208975 & 0.059066 & -3.537970 & 0.0007 \\
KSI81 & -0.757835 & 0.465487 & -1.628047 & 0.1078 \\
PROD81 & 0.034014 & 0.015395 & 2.209449 & 0.0303 \\
NEDUM & -0.423869 & 0.161632 & -2.622440 & 0.0106 \\
NWDUM & -0.208209 & 0.115581 & -1.801415 & 0.0758 \\
SCDUM & -0.653933 & 0.128807 & -5.076830 & 0.0000 \\
WADUM & -0.457059 & 0.168791 & -2.707837 & 0.0084 \\
CAPCIT & 0.385966 & 0.210539 & 1.833231 & 0.0708 \\
NEWTOWN & 0.570858 & 0.118864 & 4.802611 & 0.0000 \\
\hline \hline R-squared & 0.706619 & Mean dependent var & 0.756988 \\
Adjusted R-squared & 0.662410 & \multicolumn{2}{c}{ S.D. dependent var } & 0.508699 \\
S.E. of regression & 0.295567 & Akaike info criterion & 0.530315 \\
Sum squared resid & 6.377248 & Schwarz criterion & 0.875160 \\
Log likelihood & -10.53840 & \multicolumn{2}{l}{ Hannan-Quinn criter. } & 0.669022 \\
F-statistic & 15.98389 & Durbin-Watson stat & 2.132162 \\
Prob(F-statistic) & 0.000000 & & &
\end{tabular}


Table 5: Wage-based Ranking of Nine Occupational Groups

\begin{tabular}{|llll|}
\hline $\begin{array}{l}\text { Median } \\
\text { Wage } \\
\text { Ranking }\end{array}$ & $\begin{array}{l}\text { Occupational Group } \\
\text { (by Skill Level) }\end{array}$ & $\begin{array}{l}\text { Median Hourly } \\
\text { Wage } £ ~ 1998\end{array}$ & $\begin{array}{l}\text { Median Hourly } \\
\text { Wage £ 2016 }\end{array}$ \\
\hline 1 & $\begin{array}{l}\text { 2. Professionals } \\
\text { 1. Managers and senior } \\
\text { officials }\end{array}$ & 13.81 & 19.75 \\
3 & $\begin{array}{l}\text { 3 Associate professional } \\
\text { and technical }\end{array}$ & 9.89 & 19.73 \\
4 & $\begin{array}{l}\text { 5. Skilled trades } \\
5\end{array}$ & 7.48 & 15.00 \\
6 & $\begin{array}{l}\text { 8. Process, plant and } \\
\text { machine operatives }\end{array}$ & 6.34 & 11.50 \\
7 & $\begin{array}{l}\text { 4. Administrative and } \\
\text { secretarial }\end{array}$ & 6.28 & 10.20 \\
8 & $\begin{array}{l}\text { 6. Caring, leisure and } \\
\text { other services }\end{array}$ & 5.14 & 10.54 \\
9 & $\begin{array}{l}\text { 7. Sales and customer } \\
\text { service }\end{array}$ & 4.78 & 8.87 \\
9. Elementary & 4.59 & 8.12 \\
\hline
\end{tabular}

Source: ONS Annual Surveys of Hours and Earnings 1998 and 2016 Tables 2.5 
Figure 1: Growth in high skill occupations (Level 4) 1981-2015 against share of employment in these occupations in 1981, for 85 British cities

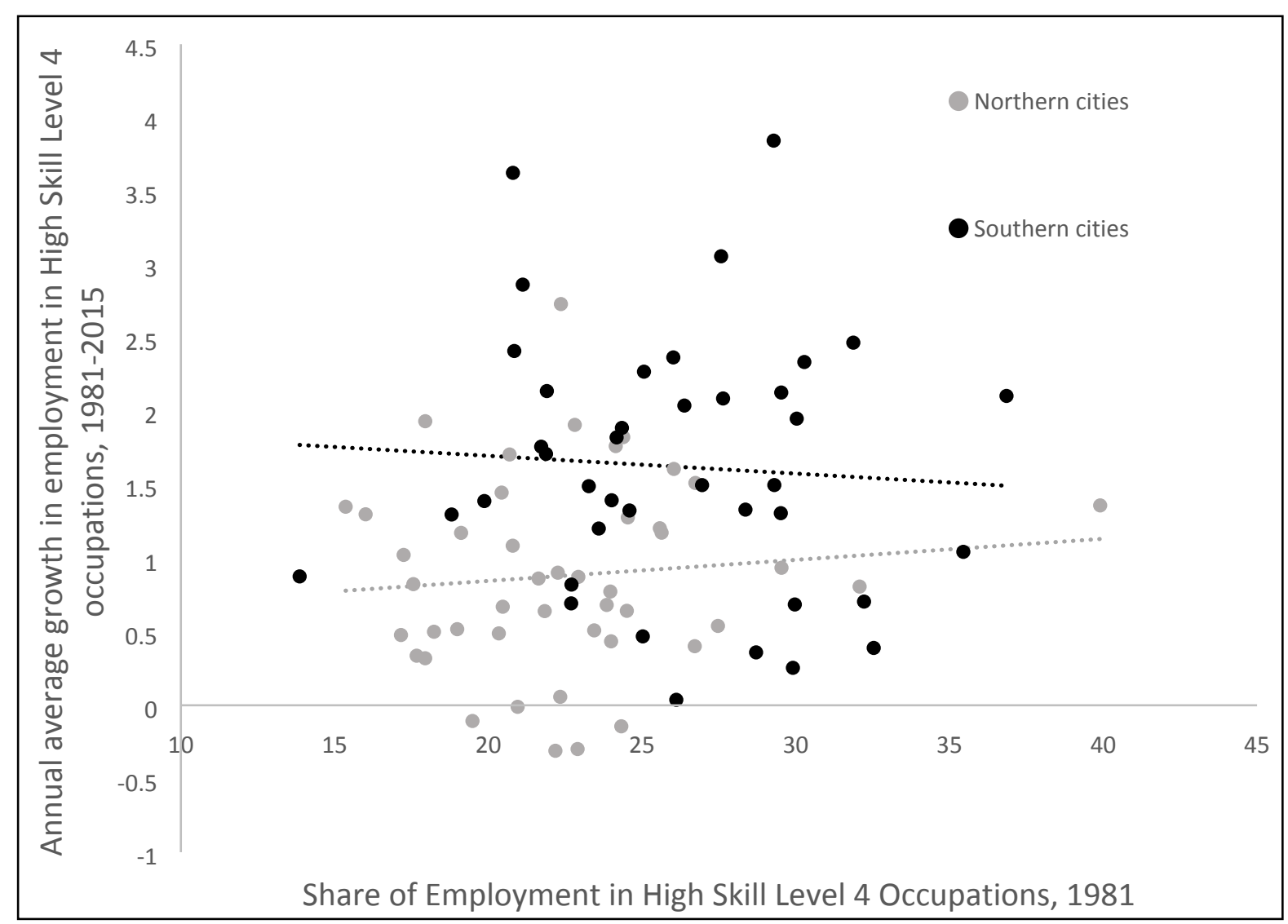

Note: $\mathrm{R}^{2}$ values refer to regression of High Skill Employment growth 1981-2015, on High Skill Employment levels in 1981, for Northern and Southern cities as separate groups 


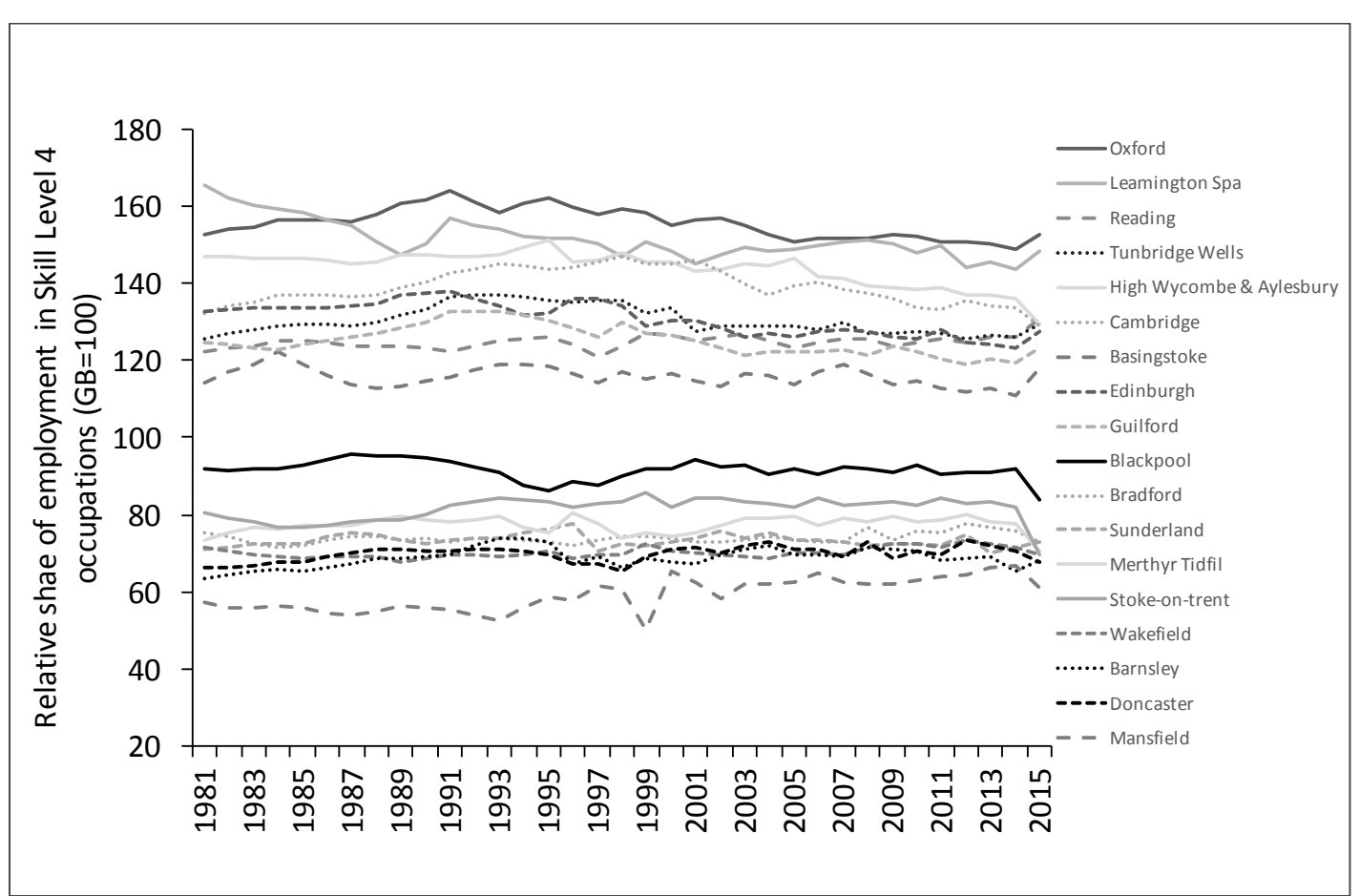

Figure 2: Relative Share of Employment in High Skill Level 4 Occupations in Most and Least Skilled Cities, 1981-2015, GB=100 


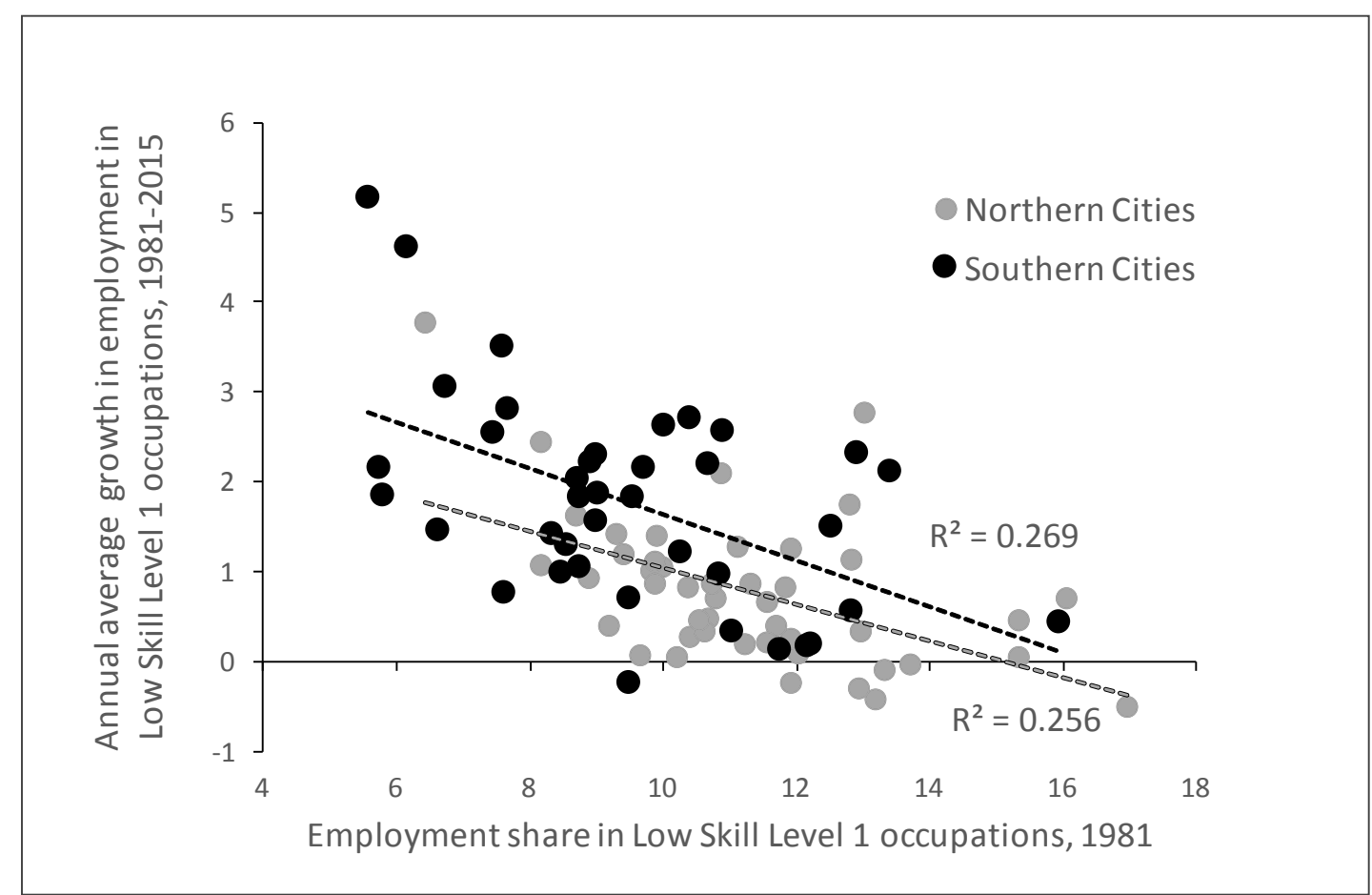

Figure 3: City Employment Growth in Low Skill (Level 1) Occupations against Low Skill Employment Share, 1981 


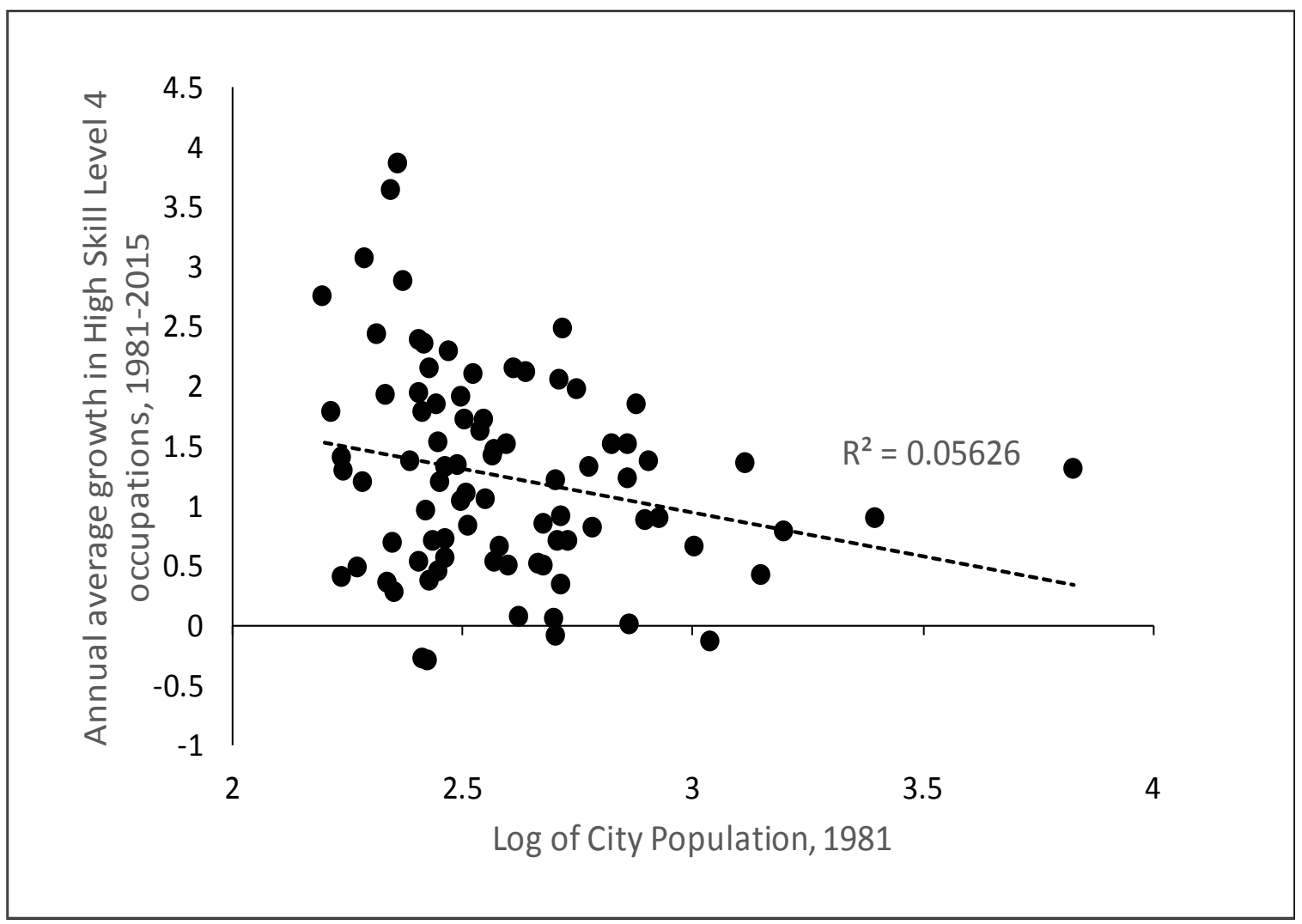

Figure 4: City Employment Growth in High Skill (Level 4) Occupations, against City Population size 1981 


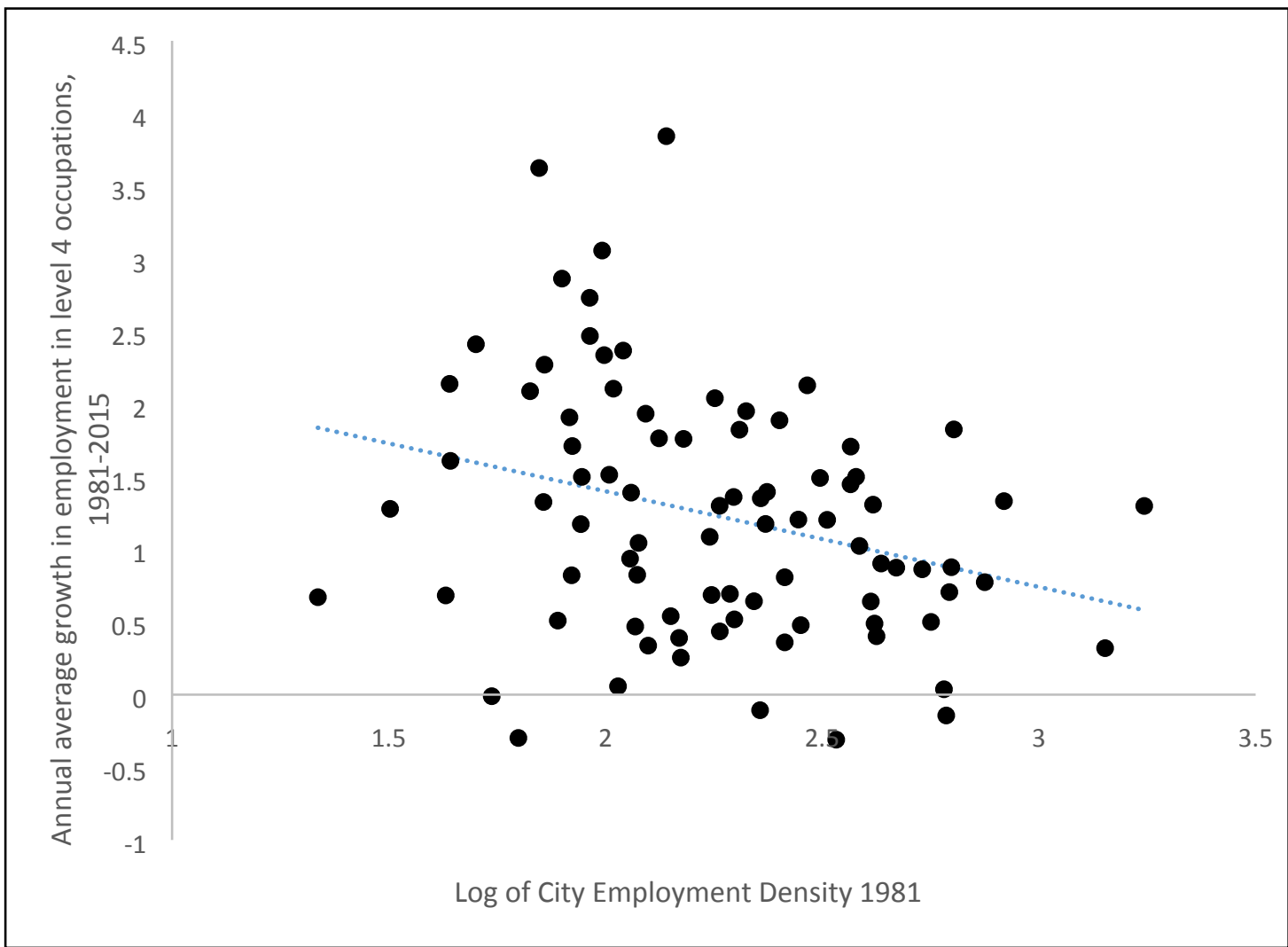

Figure 5: City High Skill Employment (Level4) growth against City Employment Density in 1981 


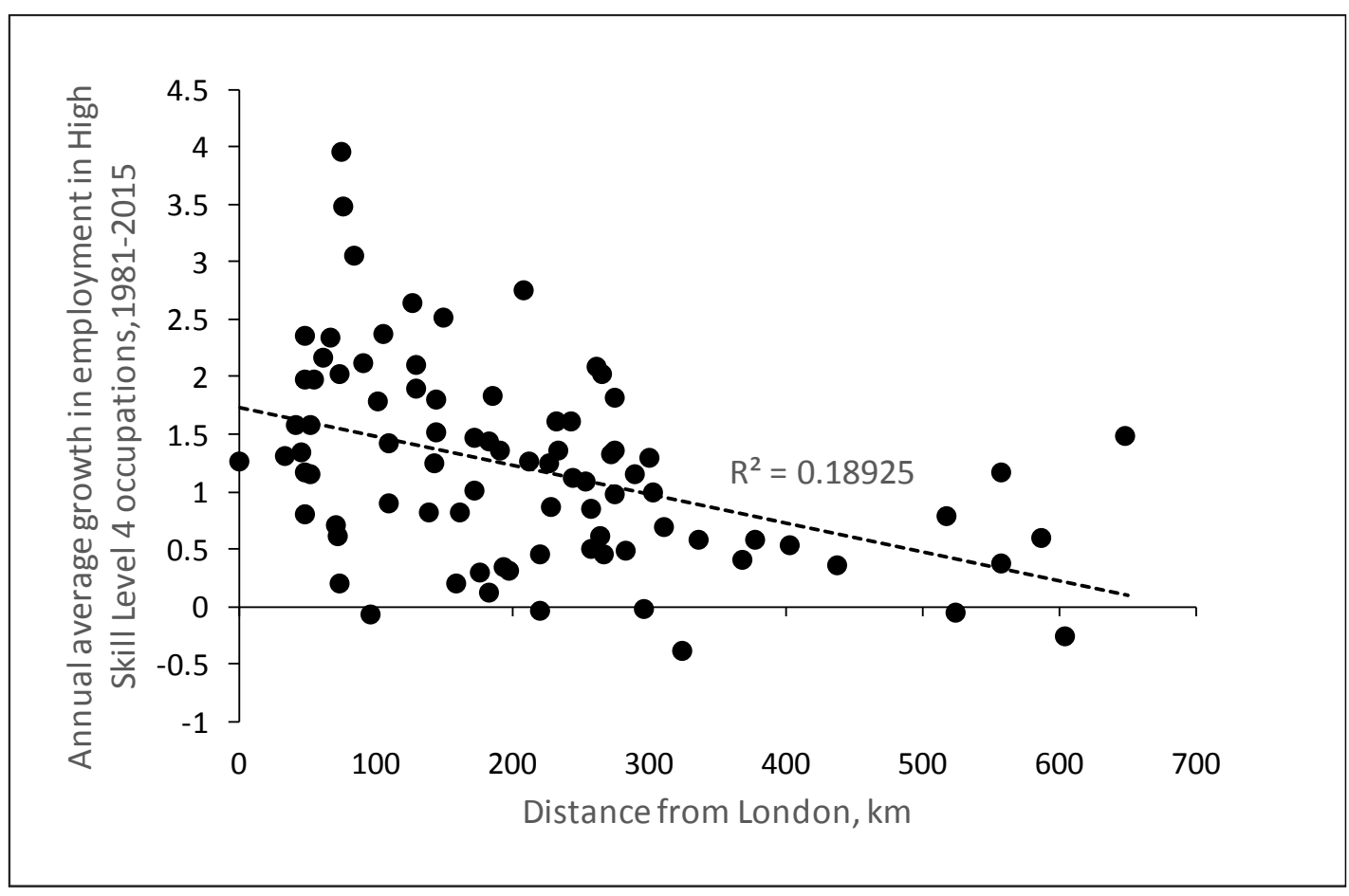

Figure 6: City Growth in High Skilled Occupations (Level 4), 1981-2015, against Distance to London 


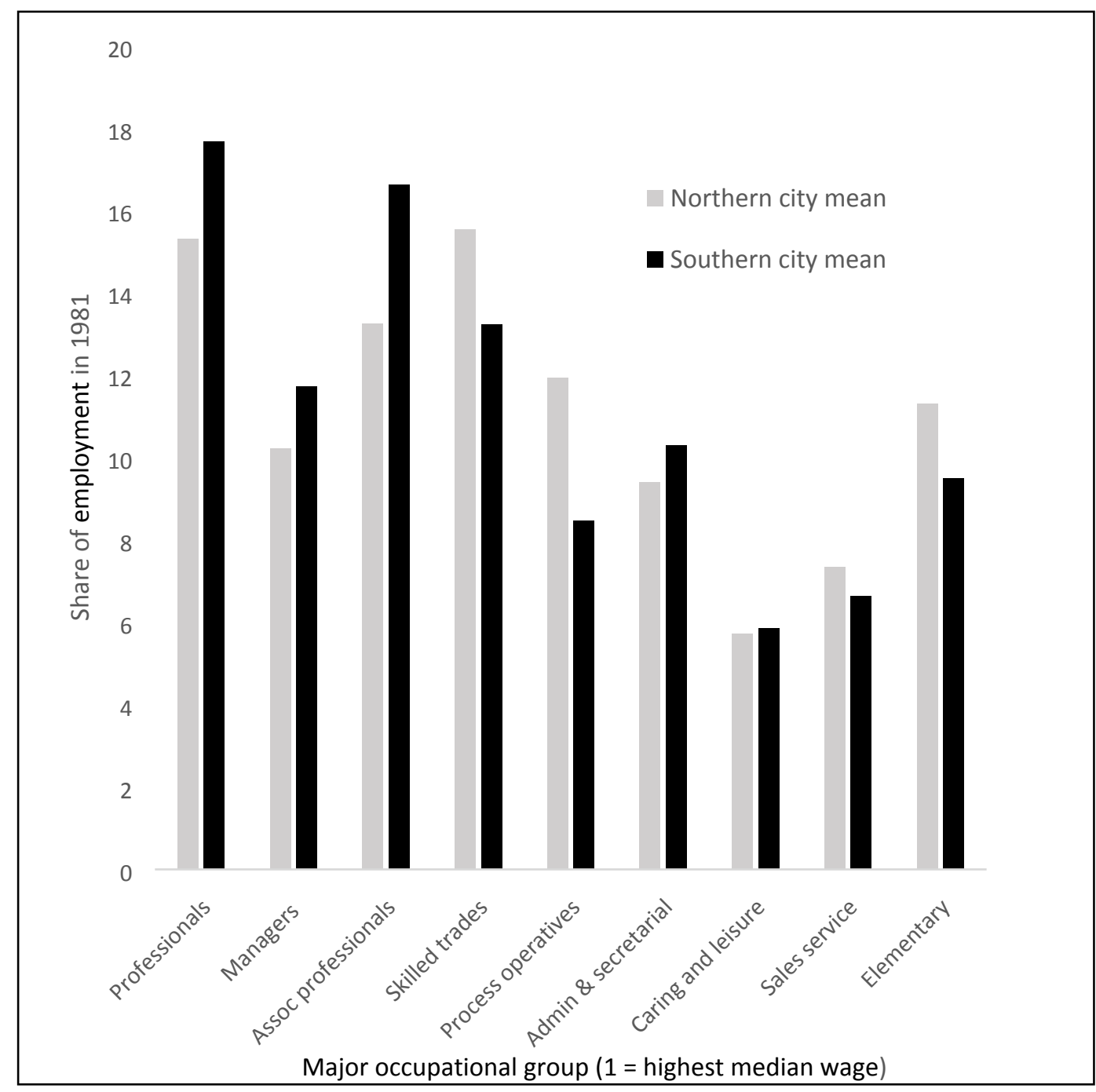

Figure 7: Share of employment in Major Occupational Group (ranked according to 1998 Median Hourly Wages), in Northern and Southern Cities in 1981 


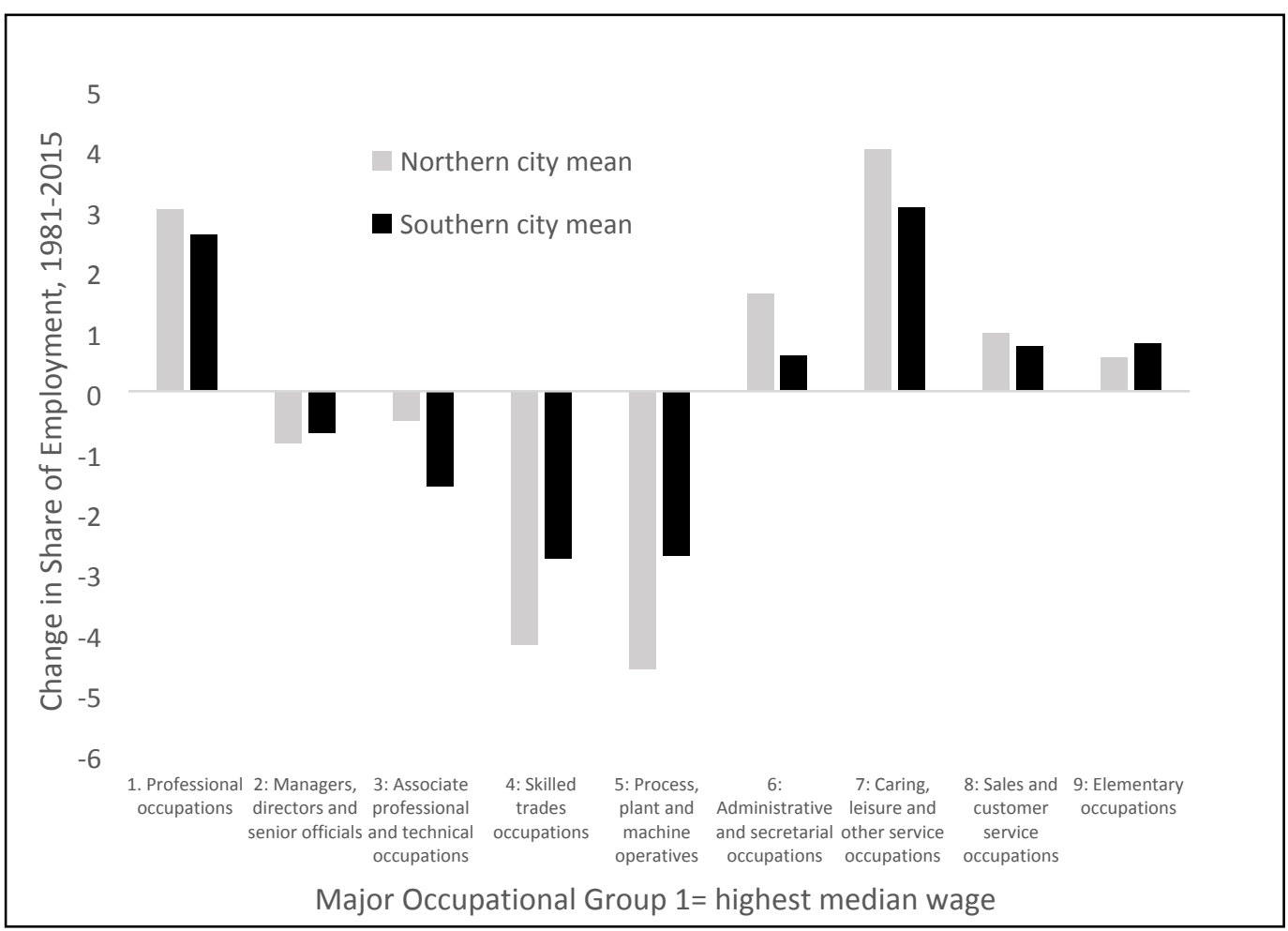

Figure 8: Change in Share of Employment in Major Occupational Groups in Northern and Southern Cities, 1981-2015 


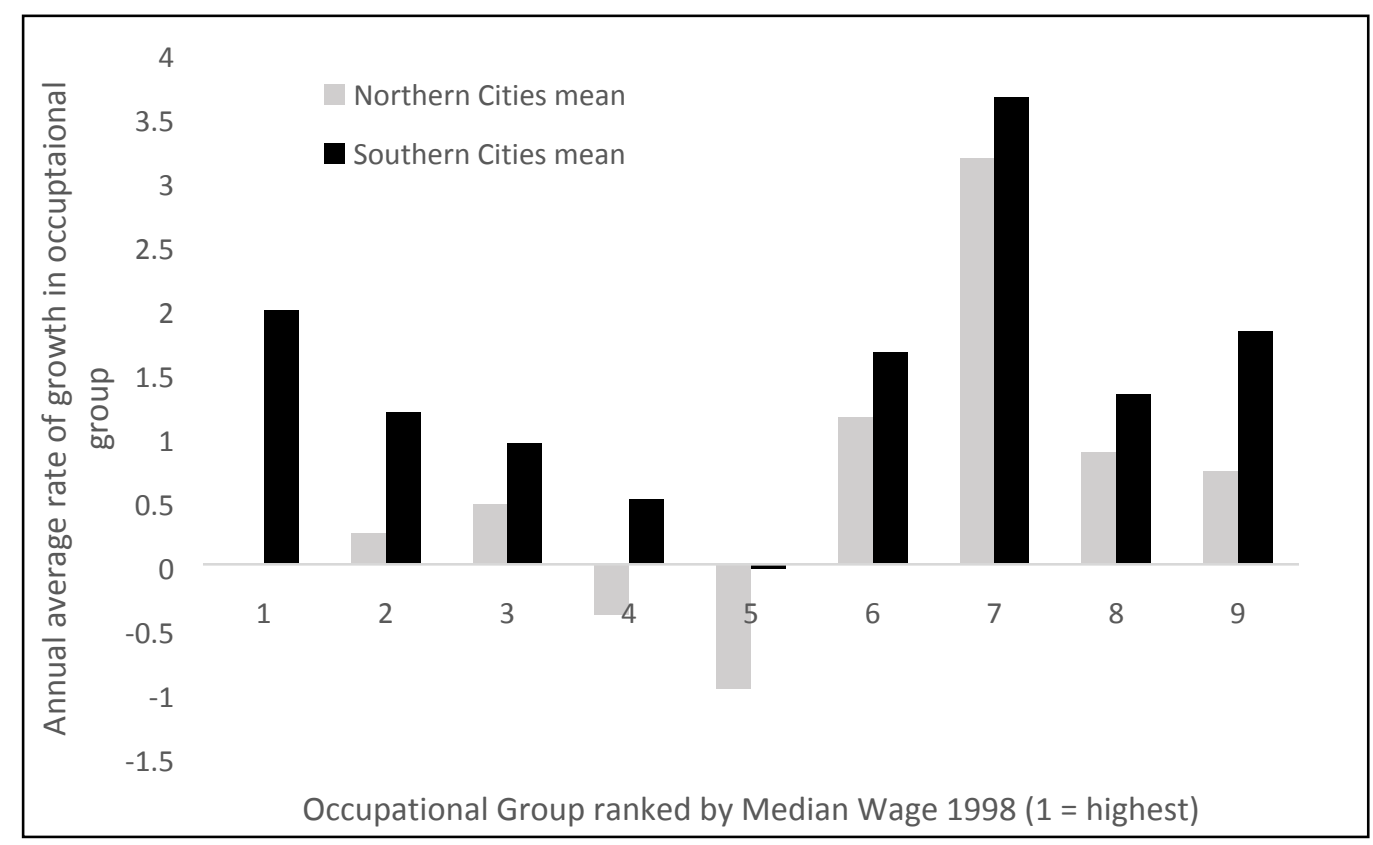

Figure 9: Change in employment in occupational groups ranked by median wages in northern and southern cities, 1981-2015 


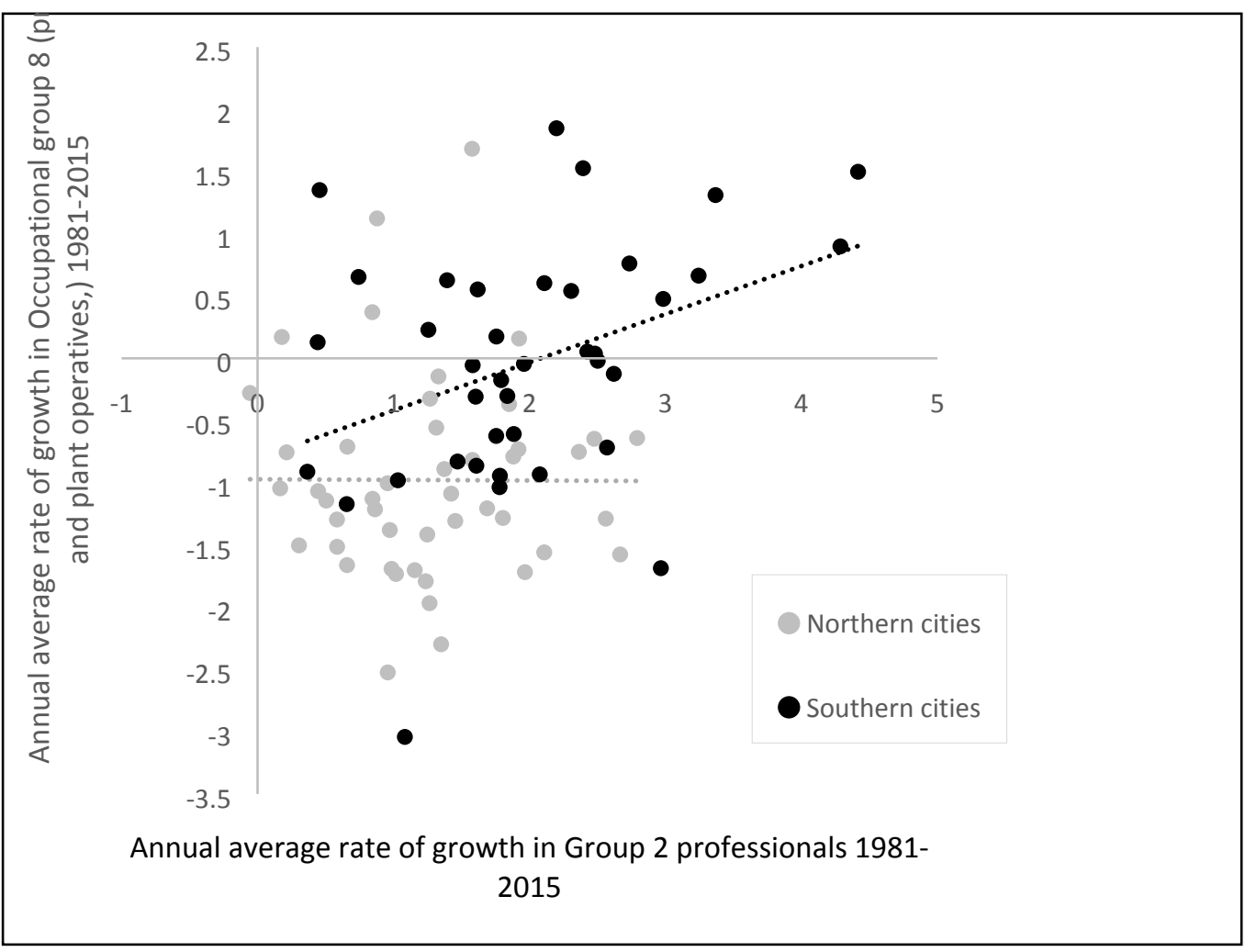

Figure 10: Change in high and medium wage occupational groups in cities, 1981-2015 